\title{
Seguimiento radiológico en paciente con fibroma condromixoide del seno frontal. Diagnóstico diferencial, alternativas terapéuticas y revisión de la literatura
}

\author{
Radiological follow-up of a patient with chondromyxoid fibroma of the frontal \\ sinus. Differential diagnosis, therapeutic alternatives and a revision of the \\ literature
}

\author{
I. Zubillaga Rodriguez1, S. Heredero Jung², M. Castrillo Tambay², G. Sanchez Aniceto', J.J. Montalvo3
}

Resumen: Introducción. El fibroma condromixoide es un tumor benigno de crecimiento lento y poco frecuente. Su incidencia en la región craneofacial es rara, especialmente en el seno frontal. Objetivos. Presentamos el seguimiento a largo plazo de un paciente intervenido en relación a un fibroma condromixoide del seno frontal. Se discuten los distintos diagnósticos diferenciales y las alternativas terapéuticas. Discusión. Desde el punto de vista de anatomía patológica es necesario hacer el diagnóstico diferencial con condrosarcoma, mixosarcoma, mixoma y cordoma. Desde el punto de vista radiológico, el diagnóstico de fibroma condromixoide ha de ser considerado en toda lesión ósea aislada con expansión u osteolisis, márgenes lobulados y septos intralesionales. El tratamiento del fibroma condromixoide incluye principalmente curetaje o resección en bloque, mientras que la radioterapia aislada no se considera de primera elección. Conclusiones. La naturaleza benigna del fibroma condromixoide implica la importancia de evitar tratamientos radicales. El abordaje subcraneal se presenta como una alternativa válida para el tratamiento de lesiones localizadas en el seno frontal. Es fundamental un seguimiento clínico-radiológico adecuado para identificar precozmente posibles recidivas.

Palabras clave: Fibroma condromixoide; Seno frontal; Abordaje subcraneal.

Recibido: 19.10 .05

Aceptado: 06.10.06
Abstract: Introduction. Chondromyxoid fibroma is a slow growing and rare benign bone tumor. Its location in the craniofacial skeleton is not common, especially in the frontal sinus. Objectives. We present a long-term follow-up of a patient with a frontal chondromyxoid fibroma who was operated four years ago. We discuss the various differential diagnoses and possible treatments. Discussion. The differential diagnosis includes chondrosarcoma, myxosarcoma, myxoma and chordoma. From the radiological point of view, chondromyxoid fibroma must be always considered as a diagnostic possibility when a solitary bone lesion appears with expansion or cortical osteolysis, lobulated margins and intralesional septi. Treatment includes curettage or monoblock resection with immediate bone graft reconstruction. Radiation therapy alone must not be considered as the first therapeutic possibility. Conclusions. the benign nature of the tumor does not justify radical, unnecessary treatment. The subcranial approach is appropriate for lesions located in the frontal sinus. A clinical and radiological follow-up is needed to identify tumor relapse.

Key words: Chondromyxoid fibroma; Frontal sinus; Subcranial approach.

1 Médico Adjunto

2 Médico Residente

3 Jefe de Servicio

Servicio de Cirugía Oral y Maxilofacial.

Hospital Universitario 12 de Octubre, Madrid. España

Correspondencia:

Dr. I. Zubillaga Rodríguez

Servicio de Cirugía Oral y Maxilofacial

Hospital Universitario 12 de Octubre

Avda. de Andalucía km 5.400

28041 Madrid, España

Email: ignaciozubillaga@yahoo.es 


\section{Introducción}

El fibroma condromixoide es un tumor benigno de crecimiento lento descrito inicialmente por Jaffe y Lichtenstein ${ }^{1}$ en 1948. Es un tumor relativamente raro, con una incidencia menor del $1 \%$ de todos los tumores óseos. ${ }^{2}$ Se localiza fundamentalmente en las metáfisis proximales de los huesos largos, principalmente en tibia y fémur. ${ }^{3}$

Aproximadamente un $2 \%$ de todos los casos descritos se localizan en el esqueleto craneofacial, fundamentalmente a nivel mandibular, ${ }^{3}$ y podrían tener su origen en remanentes del cartílago de Meckel. El fibroma condromixoide tiene cierta predilección por localizarse en centros de osificación secundaria, o cerca de ellos.

Estos tumores se presentan principalmente durante la segunda y tercera décadas de la vida, aunque se han descrito casos en pacientes desde los 20 días de vida hasta los 79 años. ${ }^{4-5}$ En general no presentan predilección por uno u otro sexo, aunque en aquellos tumores de localización mandibular existe un predominio en relación de 2:1 por el sexo femenino. ${ }^{1}$

Este trabajo tiene por objeto presentar el seguimiento a largo plazo de un paciente con el diagnóstico de fibroma condromixoide del seno frontal, publicado anteriormente a modo de caso clínico enfocado desde un punto de vista anatomopatológico. ${ }^{6}$ Además, se realiza una revisión de la literatura, así como de los diagnósticos diferenciales y de las alternativas terapéuticas a tener en cuenta.

\section{Caso clínico}

El paciente es un varón de 46 años que había sido remitido al Servicio de Cirugía Oral y Maxilofacial Hospital Universitario 12 de Octubre (Madrid) por presentar una tumoración frontal supraciliar derecha de crecimiento lento y de aproximadamente 18 meses de evolución (Fig. 1). No refería antecedente traumático local ni otros antecedentes personales de interés. En la exploración física se objetivaba una lesión blanda a la palpación con aspecto de neoformación quística de aproximadamente $3 \mathrm{~cm}$ de diámetro. Era una lesión no dolorosa y sin signos locales de infección. No se apreciaba hipoestesia en el territorio de los nervios supraorbitario ni supratroclear.

En la radiología simple convencional se objetivaba una lesión redondeada y radiolúcida en seno frontal derecho, de aproxima-

\section{Introduction}

Chondromyxoid fibroma is a slow-growing benign tumor first described by Jaffe and Lichtenstein in 1948. It is a relatively rare tumor, with an incidence rate of less than $1 \%$ of all bone tumors. ${ }^{2}$ It is generally located in the proximal metaphyses of the long bones, principally the tibia and femur. ${ }^{3}$

Approximately $2 \%$ of all the cases described are located in the craniofacial skeleton, mainly in the mandible, ${ }^{3}$ and they could originate from Meckel's cartilage remains. Chondromyxoid fibroma has a certain predilection for secondary ossification centers, or near these.

These tumors commonly arise during the second and third decade in life, although cases have been described in patients at 20 days of life 4 until the age of 79.5 In general there is no sex predilection although, of the tumors located in the mandible, there is a 2:1 female predominance.

The object of this paper is to present a long-term followup of a patient with chondromyxoid fibroma of the frontal sinus, published previously as a case report from an anatomopathological point of view. ${ }^{6}$ In addition, a review of the literature and of the differential diagnoses and therapeutic alternatives to be taken into account is carried out.

\section{Case report}

The patient was a 46-year-old male that was sent to the Oral and Maxillofacial Department of the Hospital Universitario 12 de Octubre (Madrid) as a result of a frontal sinus tumor-like mass above the right eyelash, which was slowgrowing and that had been developing for approximately 18 months (Fig. 1). There was no history of local trauma nor was his medical history of interest. During the physical examination a soft lesion was noted on palpation, which appeared to be a cystic neoformation with a diameter of $3 \mathrm{~cm}$. It was non-tender and there were no local signs of infection. Hypoes- 
damente 2,5-3 cm de diámetro. Posteriormente se solicitó un TAC del esqueleto craneofacial, apreciándose nuevamente una lesión radiolúcida y bien definida ocupando la mitad superior del seno frontal derecho. Aparentemente presentaba un aspecto quístico y provocaba osteolisis tanto de la pared anterior como de la pared posterior del seno frontal (Fig. 2). La impresión diagnóstica inicial fue de mucocele con comportamiento agresivo a nivel local y afectación de la duramadre frontal.

La intervención quirúrgica se realizó bajo anestesia general. Mediante una incisión bicoronal se abordó la lesión, que aparentemente era una masa sólida y sin cápsula (Fig. 3). Se tomaron biopsias intraoperatorias de los márgenes de la lesión, que fueron catalogados como tumor mesenquimal de agresividad local. Se realizó exéresis de la lesión tumoral mediante un abordaje subcraneal, incluyendo parte del hueso frontal circundante y del pericráneo, con preservación de la duramadre frontal (después de coagulación con bipolar) (Fig. 4). Posteriormente, se utilizó un colgajo de gáleapericráneo para obturar el seno frontal y aislar el defecto craneal (Fig. 5). Además, se utilizó un injerto óseo monocortical de calota parietal para el defecto óseo de la pared anterior del seno frontal. Tanto el injerto óseo como la osteotomía para el abordaje subcraneal se fijaron con placas de titanio de bajo perfil (1,0 mm) (Fig. 6).

En el examen macroscópico se describía la tumoración como una lesión violácea y nodular de 2,5 x 2,5 × $1 \mathrm{~cm}$. Al corte, se manifestaba su aspecto fibroso, observándose en su interior una formación quística de 0,4cm de diámetro.

Microscópicamente la lesión presentaba una morfología polilobulada, estando los lóbulos separados unos de otros por tejido conectivo ricamente vascularizado, pero con ausencia de vascularización en el interior de dichos lóbulos. Además, estos lóbulos presentaban un tamaño irregular y estaban constituidos por un estroma mixoide hierro coloidal positivo. En el seno de dicho estroma se podían observar células poligonales en lagunas, así como células fusiforme y estrelladas. Estas células se disponían más abundantemente en la periferia que en el centro de los lóbulos. No se observaron mitosis, pero

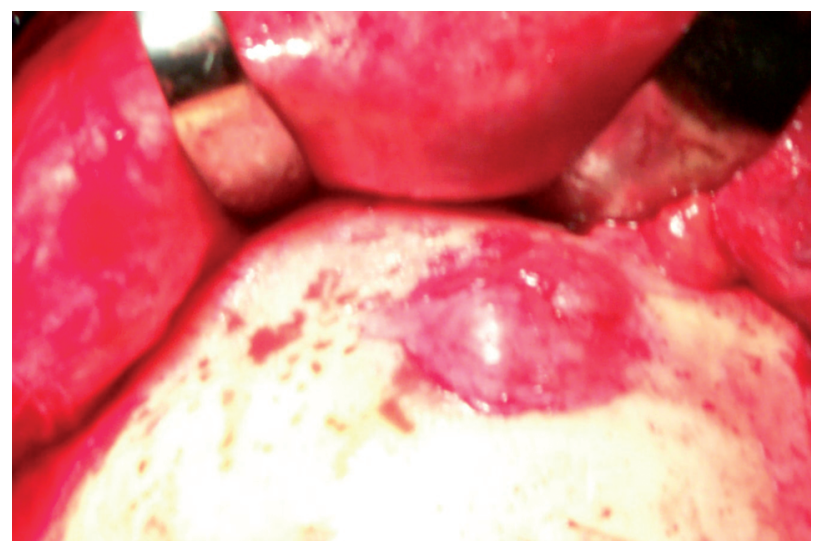

Figura 3. Visión intraoperatoria del tumor tras abordaje bicoronal. Figure 3. Intraoperative view of the tumor after a bicoronal approach.

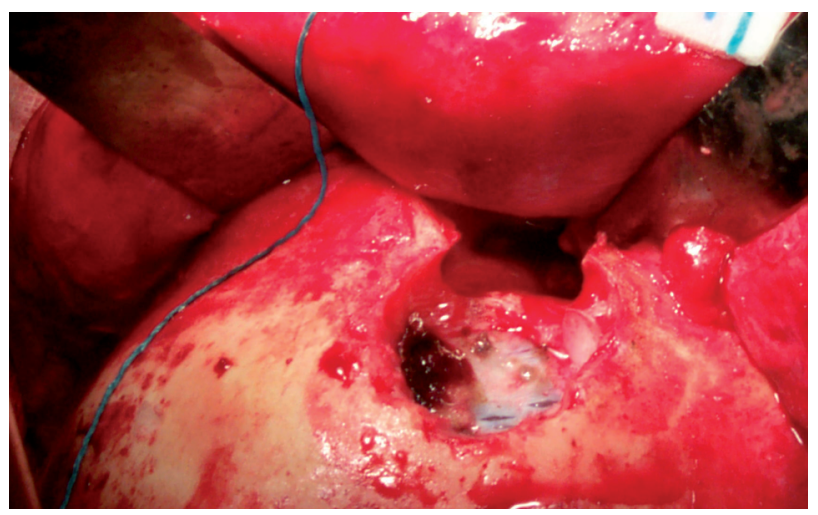

Figura 4. Lecho tras resección tumoral.

Figure 4. Tumor bed after resection.

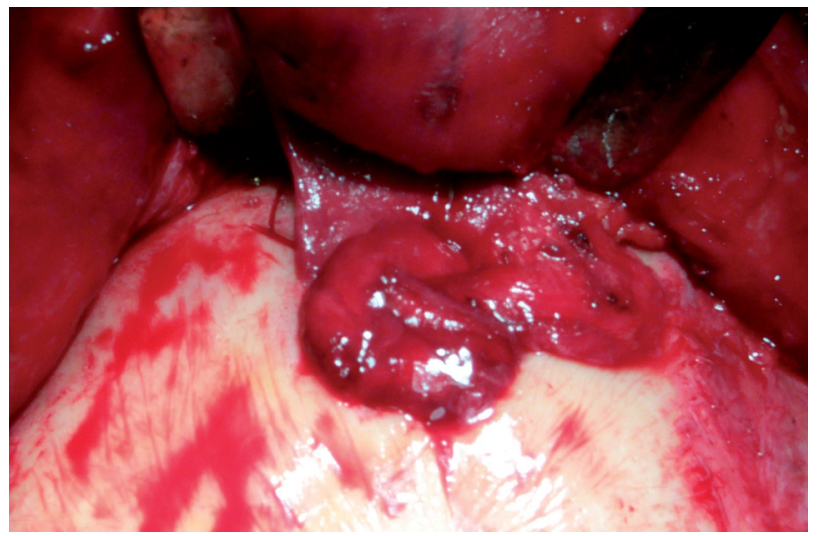

Figura 5. Colgajo de gálea-pericráneo para obturar el seno frontal.

Figure 5. Galeopericranial flap for obturating frontal sinus. thesia was not appreciated in the area of the supraorbital or supratrochlear nerves.

The conventional plain radiography showed a rounded and radiolucid lesion in the right frontal sinus with a diameter of approximately 2.5-3 cm. A CAT scan was later requested of the craniofacial skeleton, and again a radiolucid lesion that was well-defined could be appreciated. It was occupying the upper half of the right frontal sinus. It had a cystic appearance and it had led to osteolysis of the anterior as well as posterior wall of the frontal sinus (Fig. 2). The initial diagnostic impression was of mucocele with aggressive local behavior and involvement of the frontal dura mater.

The surgical intervention was carried out under general anesthesia. The lesion was approached by means of a bicoronal incision. The mass appeared to be solid and with no capsule (Fig. 3). Biopsies were taken intraoperatively of the lesion margins, which was categorized as a locally aggressive mesenchymal tumor. Exeresis was carried out of the tumor lesion by means of a subcranial approach that included part of the surrounding frontal bone and the pericranium with preservation of the frontal dura mater (after bipolar coagulation) (Fig. 4). Later a galeopericranial flap was used for sealing the frontal sinus and for isolating the cranium defect (Fig. 5). A monocortical bone graft of parietal calvarium was used for the bone defect of the anterior wall of the frontal sinus. The bone graft as well as the osteotomy carried out for the subcranial approach, were fixed with lowprofile titanium plates $(1.0 \mathrm{~mm}$ ) (Fig. 6). 
si pequeñas calcificaciones y focos de necrosis.

La microscopía electrónica mostraba células estrelladas multipolares en el seno de un estroma fibromixoide, con un material algodonoso rodeando las membranas celulares. Las membranas celulares no presentaban estructuras de superficie y en el citoplasma no se evidenciaba aumento de ninguna de las organelas. El diagnóstico fue de proliferación mesenquimal con diferenciación condral.

Finalmente, el estudio de inmunohistoquímica reveló el diagnóstico de neoformación con fenotipo condral, lo que fue congruente con el diagnóstico histopatológico de fibroma condromixoide. Después de la intervención quirúrgica y de un postoperatorio sin complicaciones, el paciente fue dado de alta y controlado periódicamente. Se le realizó un TAC de control al cabo de 1 año (Fig. 7) sin evidenciarse alteraciones radiológicas sugerentes de una recidiva de la lesión. A los 2 años de la intervención, el paciente continuaba clínicamente asintomático (Fig. 8), con un TAC sin indicios de recidiva (Fig. 9). En el último TAC de control (Fig. 10), realizado a los 4 años del tratamiento quirúrgico, tampoco se observaron lesiones radiológicas sugerentes de una recidiva. Además, puede observarse el injerto óseo de calota fijado con titanio, material que no ha ocasionado intolerancia hasta el momento. El paciente continúa actualmente asintomático.

\section{Discusión}

\section{Revisión de la literatura}

En la clasificación de tumores óseos primarios fue Lichtenstein ${ }^{7}$ en 1951 quien describió por primera vez el fibroma condromixoide como una entidad patológica perteneciente al grupo de tumores benignos derivados de cartílago. Posteriormente, Jaffe, ${ }^{8}$ en 1958 recogió más de 30 casos con este diagnóstico.

En la mayoría de las series publicadas se incluyen casos de localización en extremidades inferiores, ya que la localización más frecuente del fibroma condromixoide es la zona metafisaria de los huesos largos de las extremidades inferiores, principalmente tibia y fémur. Así, Feldman y cols, ${ }^{5}$ (1970) recogen 207

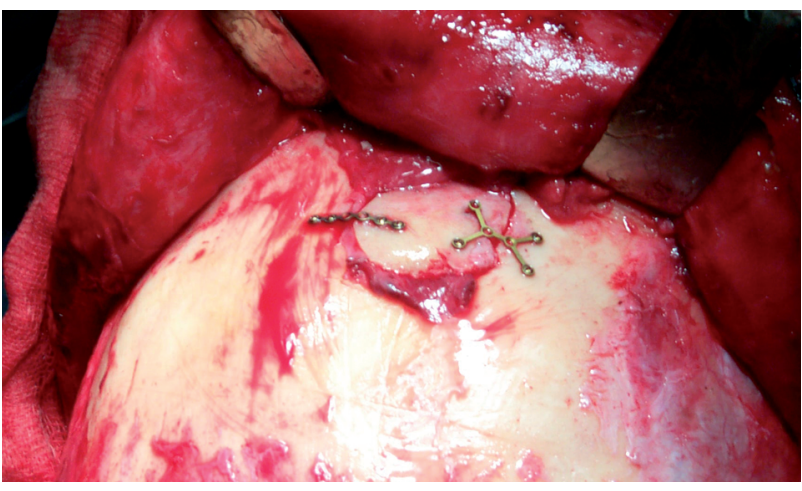

Figura 6. Injerto monocortical de calota fijado con placa de titanio $(1.0 \mathrm{~mm})$.

Figure 6. Monocortical graft of calvarium fixed with a titanium plate $(1.0 \mathrm{~mm})$.

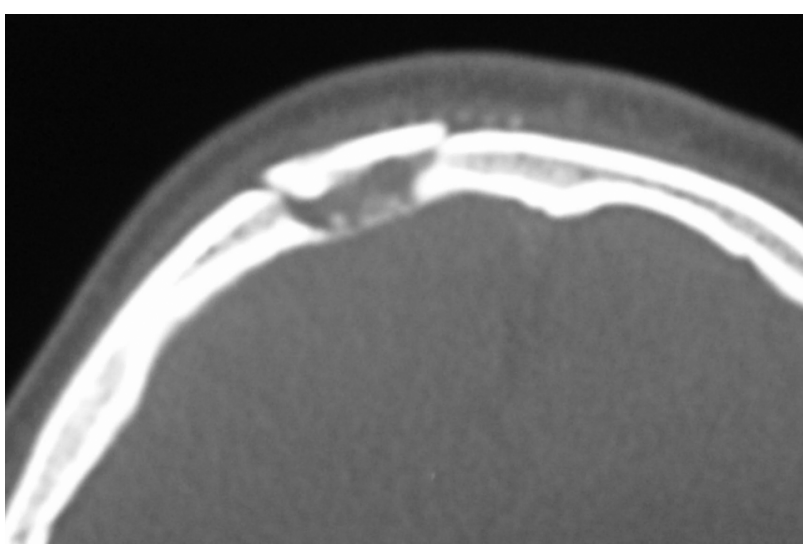

Figura 7. TAC 1 año después de la intervención quirúrgica. Figure 7. CAT scan a year after surgery.

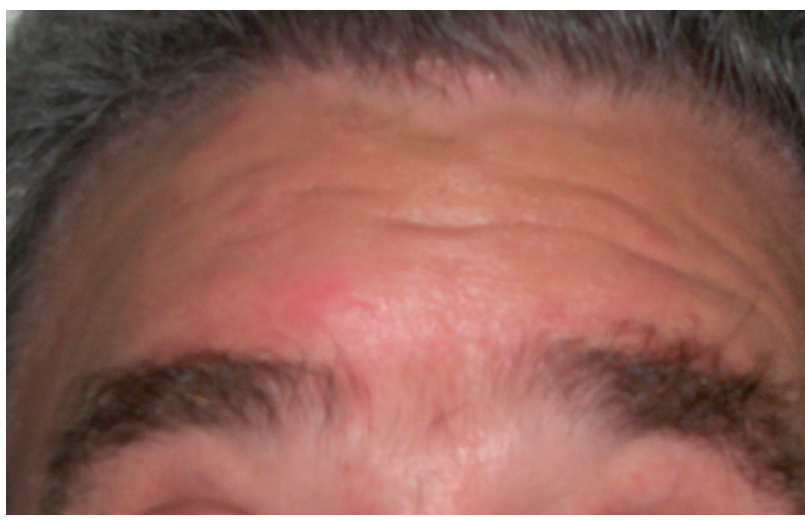

Figura 8. Paciente clínicamente asintomático a los 2 años del tratamiento.

Figure 8. Clinically asymptomatic patient two years after treatment.
The macroscopic examination described the tumorlike mass as a purplish and nodular lesion measuring $2.5 \times 2.5 \times 1 \mathrm{~cm}$. When sectioned it appeared fibrous and it had a cystic formation in its interior. It had a diameter of $0.4 \mathrm{~cm}$. Microscopically the lesion had a polylobulated morphology. The lobules were separated one from the other by connective tissue that was richly vascularized, but the interior of the lobules was not vascularized. In addition, the lobules were irregular in shape and they were made up of myxoid stroma that was positive for colloidal iron. In the center of the stroma, polygonal cells could be observed in round sheets as well as fusiform and stellate cells. These cells were more abundant around the edges than in the centers of the lobules. Mitoses were not observed, although there were small calcifications and necrotic foci.

Electron microscopy showed multipolar stellate cells in the center of fibromyxoid stroma with cotton woollike material surrounding the cell membranes. The cell membranes did not have surface structure and in the cytoplasm there was no evidence of any of the organelles increasing. The diagnosis was of mesenchymal cell proliferation with chondral differentiation.

The immunohistochemical study finally gave the diagnosis of neoformation with chondral phenotype, which coincided with the histopathological diagnosis of chondromyxoid fibroma.

After the surgical intervention and a postoperative period that was complication-free, the patient was discharged and 
casos; Salzer y Salzer-Kuntschik, ${ }^{9}$ (1965), 117 casos; Frank y Rockwood, ${ }^{10}$ (1969), 91 casos y Rahimi y cols, ${ }^{11}$ (1972) revisan 76 casos. Otras series con menor número de pacientes son los 41 casos recogidos por el Comité de Tumores Óseos de la Asociación Japonesa de Ortopedia, ${ }^{12}$ y los 32 casos recogidos por Schajowicz y Gallardo (1971). ${ }^{13}$

El primer caso de fibroma condromixoide de localización craneofacial fue publicado en 1958 por Jaffé, 8 quien recogió un caso de localización parietal. La localización craneofacial más frecuentemente afectada es la mandíbula, ${ }^{2}$ siendo el primer caso descrito en 1951 por Paul. ${ }^{14}$ Generalmente, la integridad de periostio evita la afectación extraósea, pero Lingen ${ }^{15}$ presentó en 1993 un caso de fibroma condromixoide mandibular con afectación extraósea en el momento del diagnóstico. Otras localizaciones dentro del esqueleto craneofacial que han sido descritas son: premaxila, ${ }^{16}$ base de cráneo, ${ }^{17-19}$ región occipital ${ }^{11}$ y espacio pterigopalatino. ${ }^{20}$

Respecto a la afectación del hueso frontal, ésta es una localización muy poco frecuente para el fibroma condromixoide. Los casos descritos en la literatura se esquematizan en la tabla 1.

\section{Diagnóstico diferencial}

Es necesaria una cuidadosa correlación de los hallazgos clínicos, radiológicos e histológicos para obtener un diagnóstico correcto.

De acuerdo con la definición de la Organización Mundial de la Salud, ${ }^{29}$ Se considera fibroma condromixoide como aquel tumor benigno caracterizado por la presencia de áreas de células estrelladas o festoneadas con abundante material mixoide o condroide intercelular, separadas por zonas ricas en células redondeadas con un número variable de células gigantes multinucleadas de diferentes tamaños.

La presencia de grandes células pleomórficas puede dar lugar a confusión con el condrosaroma. De hecho, uno de los mayores puntos de interés en el manejo de estos tumores es el diagnóstico diferencial con los condrosarcomas de bajo grado. Dicha entidad puede presentar también áreas mixoides prominentes, células periféricas con núcleos bizarros y células pleomórficas con núcleos hipercromáticos. ${ }^{30}$ Los hallazgos histopatológicos de ambas lesiones son muy similares, sin embargo, los condrosarcomas de bajo grado típicamente carecen de los límites bien circunscritos que rodean la lesión, así como de los septos fibrosos que dividen en áreas (pseudolóbulos) al fibroma condromixoide. Además, en el fibroma condromixoide se observa un mayor celularidad y más células gigantes multinucleadas en la periferia tumoral.

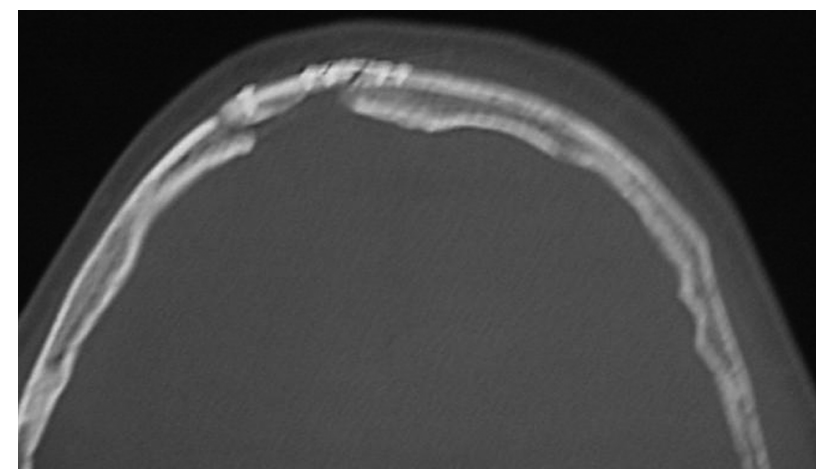

monitored periodically. A follow-up CAT scan was carried out after a year (Fig. 7) and there were no radiological changes suggestive of recurrence. Two years after the intervention, the patient was clinically asymptomatic (Fig. 8), with CAT scans showing no sign of recurrence (Fig. 9). In the last check-up by CAT scan (Fig. 10) carried out four years after the surgical treatment, lesions were not observed radiologically that were suggestive of recurrence. In addition, a graft of calvarium fixed with titanium can be observed, and no intolerance to this material has arisen to date. The patient continues being asymptomatic.

\section{Discussion}

Revision of the literature With regard to bone tumor classification, it was Lichtenstein ${ }^{7}$ who first described in 1951 the chondromyxoid fibroma as a pathologic entity belonging to the group of benign tumor arising from the cartilage. Later Jaffe 8 in 1958 recorded more than 30 cases with this diagnosis.

Most of the series published include cases involving the lower extremities, as the most common location of the chondromyxoid fibroma is the metaphyseal area of the long bones of the lower extremities, principally the tibia and the femur. Feldman and col 5 (1970) recorded 207 cases; Salzer and Salzer-Kuntschik9 (1965) 117 cases; Frank and Rockwood ${ }^{10}$ (1969) 91 cases, and Frank and Rockwood 10 (1972) reviewed 76 cases. Other series with lower patient numbers are the 41 cases collected by the Bone Tumor Committee of the Japanese Orthopaedic Association National Cancer Center, 12 and the 32 cases collected by Schajowicz and Gallardo ${ }^{13}$ (1971).

The first cases of chondromyxoid fibroma with a craniofacial location were published in 1958 by Jaffe, 8 who recorded a case in the parietal area. The craniofacial area most commonly affected is the mandible, ${ }^{2}$ and the first case was described by Paul. ${ }^{14}$ Generally, the integrity of the periosteum avoids extraosseous involvement, but Lingen ${ }^{15}$ presented in 1993 a case of mandibular chondromyxoid fibroma with extraosseous involvement at diagnosis. Other locations within the craniofacial skeleton that have been described 
Tabla 1. Casos publicados de fibroma condromixoide de localización frontal

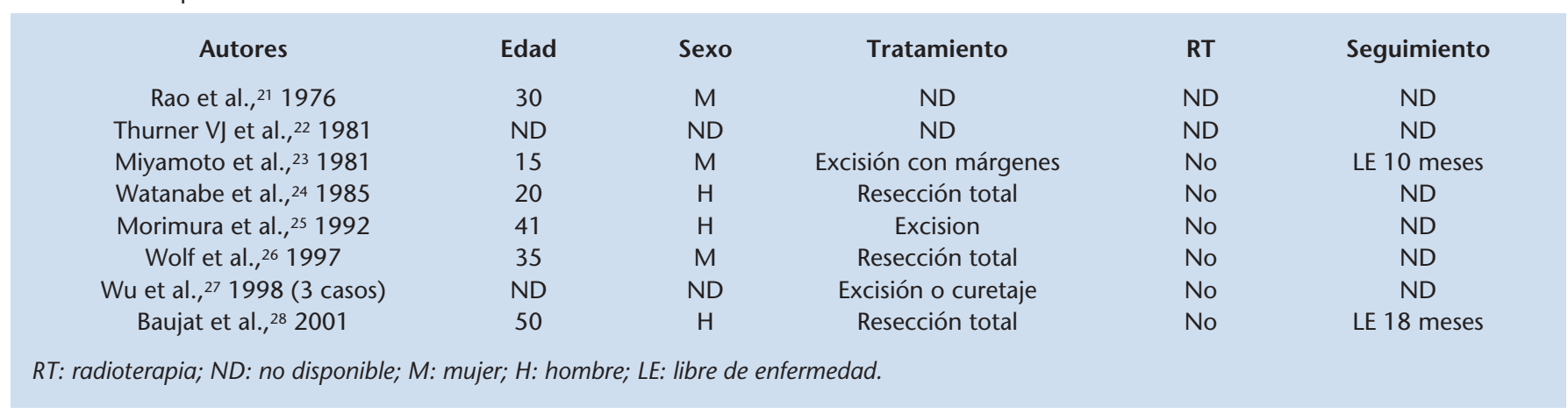

Table 1. Cases published of chondromyxoid fibroma with a frontal location

\begin{tabular}{|c|c|c|c|c|c|}
\hline Authors & Age & Sex & Treatment & RT & Follow-up \\
\hline Rao et al., ${ }^{21} 1976$ & 30 & $\mathrm{~F}$ & NA & NA & NA \\
\hline Thurner VJ et al.,22 1981 & NA & NA & NA & NA & NA \\
\hline Miyamoto et al.,23 1981 & 15 & $\mathrm{~F}$ & Excision with margins & No & DF 10 months \\
\hline Watanabe et al., ${ }^{24} 1985$ & 20 & M & Total resection & No & NA \\
\hline Morimura et al.,25 1992 & 41 & M & Excision & No & NA \\
\hline Wolf et al., ${ }^{26} 1997$ & 35 & $F$ & Total resection & No & NA \\
\hline Wu et al., ${ }^{27} 1998$ (3 cases) & NA & NA & Excision or curettage & No & NA \\
\hline Baujat et al., 282001 & 50 & $M$ & Total resection & No & DF 18 months \\
\hline
\end{tabular}

$R T$ : radiotherapy; NA: not available; F: female; M: male; DF: disease-free.

Por otra parte, la positividad para S-100 apoya el origen cartilaginoso del fibroma condromixoide, ya que las áreas mixomatosas son negativas para dicha proteína. Sin embargo, hay que considerar que un resultado positivo para S-100 no excluye que la lesión sea un condrosarcoma, de ahí su escaso interés y baja sensibilidad para el diagnóstico diferencial de dichas lesiones. ${ }^{15}$

Estudios preliminares de la composición química del fibroma condromixoide revelan la presencia de niveles elevados de ácido glutámico en la matriz tumoral, ${ }^{2}$ hecho no observado en el condrosarcoma. La medida del contenido de ADN celular por citometría de flujo puede ser de ayuda para distinguir algunos tipos de neoplasias benignas de malignas. Las lesiones condroides benignas tienen un contenido normal de ADN (rango diploico). Aproximadamente el $60 \%$ de los condrosarcomas presentan un contenido anormal de ADN, hecho que no es observable en las neoplasias benignas. Así, mientras que un contenido normal de ADN no excluye el diagnóstico de condrosarcoma, un contenido anormal de ADN (aneuploidía) en una neoplasia condroide identifica al condrosarcoma. ${ }^{31}$

Cuando la matriz es menos condroide y predominantemente mixoide hay que establecer el diagnóstico diferencial con el mixosarcoma. El diagnóstico de mixoma puede ser excluido por la ausencia de reacción a la mucina de dicho tumor y además, la condensación de células tumorales en la periferia de la lesión está en contra del diagnóstico de mixoma.

Otro diagnóstico diferencial ha de establecerse con el cordoma, lesión tumoral que al igual que el condrosarcoma tiene un comportamiento más agresivo y es capaz de producir metástasis a distancia. Para diferenciar cordoma de fibroma condromixoide es importante considerar que el primero presental márgenes infiltrativos, una are: premaxila, ${ }^{16}$ skull base, ${ }^{17-19}$ occipital region, ${ }^{11}$ and pterygoplatine space. ${ }^{20}$

With regard to frontal bone involvement, it is very uncommon for the chondromyxoid fibroma to be located here. The cases described in the literature are set out in table 1.

Differential diagnosis

A careful correlation is necessary of the clinical, radiological and histological findings in order to reach a correct diagnosis.

According to the World Health Organization, 29 chondromyxoid fibroma is a benign tumor characterized by the presence of areas of spindle-shaped or stellate cells with abundant myxoid or chondroid intercellular material, separated by zones rich in rounded cells with a varying number of multinucleated giant cells of different sizes.

The presence of large pleomorphic cells can lead to it being confused with the chondrosarcoma. In fact, one of the greatest points of interest in the management of these tumors involves the differential diagnosis with the low-grade chondrosarcoma. This entity can have prominent myxoid areas, peripheral cells with bizarre nuclei and pleomorphic cells with hyperchromatic nuclei. ${ }^{30}$ The histopathological findings of both lesions are very similar, however, low-grade chondrosarcoma typically lacks well-circumscribed borders around the lesion, as well as the fibrous septa that divide the chondromyxoid fibroma into (pseudolobulated) areas. In addition, a greater amount of cellularity can be observed in the chondromyxoid fibroma together with more multinucleated giant cells around the tumor edges. 
composición de células epiteliales anchas con citoplasma vacuolado o eosinofílico que forman nidos o cordones celulares y ausencia del componente fibroso de los fibromas condromixoides.

Desde el punto de vista radiológico, los hallazgos no son específicos, de ahí que sea necesario establecer el diagnóstico diferencial con las siguientes lesiones: granuloma de células gigantes, quistes óseos, encondromas, condroblastomas benignos, lesiones fibrosas benignas, quiste óseo aneurismático, displasia fibrosa monostótica, hiperparatiroidismo, mixoma y neurofibromatosis. ${ }^{32}$

\section{Tratamiento}

La elección del abordaje terapéutico más adecuado para el tratamiento del fibroma condromixoide continúa siendo controvertido. Básicamente, han sido empleadas dos modalidades de tratamiento: curetaje o resección en bloque, seguido de reconstrucción inmediata con injertos óseos. La radioterapia aislada no se considera como tratamiento de primera elección.

La naturaleza benigna del tumor con posibilidad de tratar con éxito la lesión tras una posible recurrencia, así como la deformidad estética y funcional que puede generarse tras la exéresis en bloque de la lesión, son los principales pilares que sostienen la defensa del curetaje como tratamiento de primera elección. Así, el curetaje con estrecho seguimiento posterior para poder tratar precozmente las recurrencias, es planteado como una excelente alternativa terapéutica por gran parte de los autores. Su indicación parece más clara para aquellas lesiones que afectan a los maxilares, dado que la resección en bloque puede ser un procedimiento demasiado radical teniendo en cuenta la potencial deformidad estética y funcional residual.

Por otra parte, una considerable tasa de recidiva tras curetaje (13$22 \%)^{30}$ llevaría a plantear como primera posibilidad terapéutica una resección en bloque conservadora seguida de reconstrucción inmediata con injertos óseos. En este sentido, es importante señalar que la recidiva tumoral generalmente es debida a la reseción incompleta de las extensiones lobulares tumorales. Además, la tasa de recidiva se ve aumentada en presencia de los siguientes factores: pacientes jóvenes, patrón de crecimiento multinodular y presencia de contenido mucoso tumoral. Asimismo, algunos autores también recomiendan la resección en bloque frente al curetaje por la posibilidad de transformación maligna a condrosarcoma que presenta el fibroma condromixoide, si bien esta posibilidad es muy baja.

Tradicionalmente, la radioterapia ha sido considerada de dudosa utilidad en el tratamiento del fibroma condromixoide, puesto que se relacionaba con generar una predisposición para la degeneración maligna de la lesión. Sin embargo, estudios recientes ${ }^{28}$ proponen la utilidad de la radioterapia como tratamiento coadyuvante en lesiones de localización craneofacial que no pueden resecarse de forma completa, manteniendo que solamente hay dos casos bien documentados en la literatura de degeneración maligna tras radioterapia, frente a un caso de degeneración maligna espontánea.

\section{Seguimiento radiológico}

En este artículo presentamos el caso de fibroma condromixoide frontal con el mayor seguimiento a largo plazo de la literatura. Des-
Furthermore, S-100 positivity supports the cartilaginous origins of the chondromyxoid fibroma, as the myxomatous areas are negative for this protein. However, it should be considered that a positive result for S-100 does not exclude the lesion being a chondrosarcoma, given the lack of value and low sensitivity in the differential diagnosis of these lesions. ${ }^{15}$

Preliminary studies of the chemical composition of the chondromyxoid fibroma reveal the presence of high levels of glutamic acid in the tumor matrix, ${ }^{2}$ which is not observed in the chondrosarcoma.

Analysis of cellular DNA content by flow cytometry can be of help for distinguishing benign types of neoplasms from malignant ones. Benign chondroid lesions have a normal DNA content (diploic range). Approximately $60 \%$ of chondrosarcomas have an abnormal DNA content, which is not observed in benign neoplasms. Thus, while a normal content of DNA does not exclude a diagnosis of chondrosarcoma, an abnormal content of DNA (aneuploidy) in a chondroid neoplasm identifies a chondrosarcoma. ${ }^{31}$

When the matrix is less chondroid and predominantly myxoid, the differential diagnosis with myxosarcoma should be established. The diagnosis of myxoma can be excluded because of the absence of a reaction to the mucin of this tumor and in addition, the condensation of tumor cells in the periphery of the lesion goes against a diagnosis of myxoma.

A differential diagnosis has to be established including chordoma, a tumor lesion that like the chondrosarcoma is more aggressive and capable of producing distant metastasis. In order to differentiate the chordoma from the chondromyxoid fibroma it is important to take into consideration that the former has infiltrative margins. It has a composition of wide epithelial cells, with vacuolated or eosinophilic cytoplasm that form cellular nests or cords, and there is an absence of the fibrous component found in the chondromyxoid fibroma.

From the radiological point of view, the findings are specific, and the differential diagnosis should include the following lesion: giant cell granuloma, bone cysts, enchondromas, benign chondroblastoma, benign fibrous lesions, aneurismatic bone cyst, monostotic fibrous dysplasia, hyperparathyroidism, myxoma and neurofibromatosis. 32

\section{Therapy}

Choosing the therapeutic approach most suitable for treating the chondromyxoid fibroma continues being a source of controversy. Basically, two treatment modalities have been used: curettage or en bloc resection, followed by immediate reconstruction with bone grafts. Radiotherapy on its own is not considered treatment of first choice.

The benign nature of the tumors and the possibility of treating them successfully should there be reoccurrence, as well as the aesthetic and functional deformity that can occur after en bloc exeresis of the lesion, are the principal 
pués del tratamiento aplicado, con resección completa de la lesión, el paciente continúa asintomático y sin evidencia radiológica de una recidiva de la enfermedad. Además, durante su seguimiento no se han objetivado complicaciones asociadas a la intervención quirúrgica.

Es fundamental un seguimiento clínico-radiológico adecuado para identificar precozmente las recidivas. Debido a la baja incidencia de estas lesiones en la región craneofacial no es posible hacer protocolos de manejo. Sin embargo, en la mayoría de los casos publicados en la literatura las recidivas ocurren durante el primer año del postoperatorio. ${ }^{28}$ Por tanto, es necesario hacer revisiones periódicas, con TAC anuales de control, especialmente durante los primeros años tras la intervención quirúrgica.

\section{Conclusiones}

El fibroma condromixoide debe ser siempre considerado como una posibilidad diagnóstica al evaluar una lesión ósea solitaria con destrucción geográfica y márgenes lobulados, septos intralesionales, expansión u osteolisis cortical y/o rebordes escleróticos, especialmente en pacientes que se encuentran entre la segunda y tercera décadas de la vida.

Generalmente, la integridad del periostio evita la afectación extraósea.

La naturaleza benigna del fibroma condromixoide implica la importancia de evitar tratamientos radicales innecesarios. Siempre que sea posible y pueda hacerse sin causar demasiada morbilidad, debe ser escindido con márgenes suficientes para evitar la recidiva tumoral. Además, si es necesario la reconstrucción con injertos óseos debe hacerse de inmediato tras la resección.

El abordaje subcraneal se presenta como una alternativa válida para el tratamiento de lesiones localizadas en el seno frontal.

Una cuidadosa correlación de los hallazgos clínicos, radiológicos e histológicos debe ser establecida para obtener un adecuado y definitivo diagnóstico y tratamiento que evite la recidiva tumoral.

Es imprescindible un seguimiento radiológico periódico para diagnosticar de forma precoz las posibles recidivas.

\section{Bibliografía}

1. Jaffe HL, Lichtenstein L. Chondromyxoid fibroma of bone: a distinctive benign tumour likely to be mistaken for chondrosarcoma. Arch Pathol 1948;45:541-51.

2. Pinholt E, Eldeeb M, Waite D. Chondromyxoid fibroma. Int J Oral Maxillofac Surg 1986;15:553-64.

3. Batsakis JG, Raymond AK. Pathology consultation. Chondromyxoid fibroma. Ann Otol Rhinol Laryngol 1989;98:571-2.

4. Nazeer T, Ro JY, Varma DG, de la Hermosa JR, Ayala AG. Chondromyxoid fibroma of paranasal sinuses: report of two cases presenting with nasal obstruction. Skeletal Radiol 1996;25:779-82.

5. Feldman F, Hecht, Johnston HL. Chondromyxoid fibroma of bone. Radiology 1974;94:249-60.

6. Azorín D, Gil A, Sánchez-Aniceto G, Ballestín C, Martínez-Tello F. Chondromyxoid fibroma of the frontal sinus. Case report. Br J Oral Maxillofac Surg 2003; 41:418-20. points supporting curettage as first-choice treatment. Thus, curettage, with a close follow-up in order to treat any recurrence promptly, has been established as an excellent alternative by a large proportion of authors. The indication appears clear for those lesions that affect the jaws given that en bloc resection can be too radical if we take into consideration the potential aesthetic and functional residual deformity.

On the other hand, the considerable rate of recurrence after curettage (13-22\%) $)^{30}$ points to conservative en bloc resection being the first therapeutic possibility followed by immediate reconstruction with bone grafts. In this sense, it is important to point out that tumor recurrence is generally due to the incomplete resection of the lobular extensions of the tumor. Moreover, the rate of recurrence increases if the following factors are present: young patients, multinodular growth pattern and a mucosal content within the tumor. Thus, some authors also recommend en bloc resection as opposed to curettage, given the possibility of malignant transformation to chondrosarcoma that the chondromyxoid fibroma has, even though this is a very small possibility.

Traditionally, radiotherapy has been considered of dubious value for treating a chondromyxoid fibroma, as it is linked to a disposition for the malignant degeneration of the lesion. However, recent studies ${ }^{28}$ suggest the usefulness of radiotherapy as coadjuvant treatment for lesions with a craniofacial location that cannot be resected completely, and these claim that there have only been two cases in the literature of malignant degeneration after radiotherapy, as opposed to one case of spontaneous malignant degeneration.

\section{Radiological follow-up}

In this article a case is presented of frontal sinus chondromyxoid fibroma with the longest follow-up in the literature. After the treatment, and the complete resection of the lesion, the patient continues being asymptomatic and there is no radiological evidence of disease recurrence. In addition, during the follow-up no complications in connection with the surgery were observed.

An adequate clinico-radiological follow-up is essential for identifying recurrence promptly. Given the low incidence rate of these lesions in the craniofacial region, setting out a management protocol is not necessary. However, most cases published in the literature show that recurrence occurs during the first postoperative year. ${ }^{28}$ Therefore, making periodic revisions with a yearly CAT scan revision is necessary especially during the first years after the surgery.

\section{Conclusions}

The chondromyxoid fibroma should always be considered as a diagnostic possibility when a solitary bone lesion is evaluated with geographic destruction, lobulated margins, intralesional septa, and expansion or cortical osteolysis and/or 
7. Lichtenstein L. Classification of primary tumors of bone. Cancer 1951;4:335-41.

8. Jaffe HL. Tumors and tumorous condtions of bones and joints. Lea \& Freiberg: Philadelphia 1958, pp 203-13.

9. Salzer M, Salzer-Kuntschik M. Chondromyxoid fibroma. Langenbecks Arch Chir 1965;8;312:216-31.

10. Frank WE, Rockwood CA. Chondromyxoidfibroma: review of the literature and report of four cases. S Med / 1969;62:1248.

11. Rahimi A, Beabout JW, Ivins JC, Dahlin DC. Chondromyxoid fibroma: a clinicopathologic study of 76 cases. Cancer 1972;30:726-36.

12. Bone tumor comitte of the Japanese Orthopaedic Association National Cancer Center: Collections of the Registry of Bone Tumors in Japan 1966;pp.98-9.

13. Schajowicz F, Gallardo H. Chondromyxoid fibroma (fibromyxoid chondroma) of bone. A clinico-pathological study of thirty-two cases. J Bone Joint Surg Br 1971;53:198-216.

14. Paul JK. Chondromyxosarcoma of the mandible. J Oral Surg 1951;9:319-28.

15. Lingen MW, Solt DB, Polverini PJ. Unusual presentation of a chondromyxoid fibroma of the mandible. Oral Surg Oral Med Oral Pathol 1993;75:615-21.

16. Damm DD, White DK, Geissler RH, Drummond JF, Gonty AA. Chondromyxoid fibroma of the maxilla. Electron microscopic findings and review of the literature. Oral Surg 1985;59:176-83.

17. Everke H. Ein Myxochondrom- Chondromyxoid-Fibrom - Der Schadelbasis mit Ausdehnung in der Canalis spinalis. Acta Neurochir 1996;15:150-8.

18. Koay CB, Freeland AP, Athanasou NA. Chondromyxoid fibroma of the nasal bone with extension into the frontal and etmoidal sinuses. I Laringol Otol 1995; 109:258-61.

19. Shek TWH, Peh WCG, Leung G. Chondromyxoid fibroma of skull base: a tumour prone to local recurrence. The Journal of Laringology and Otology 1999;113:380-385.

20. Toremalm NG, Linstrom C, Malm L. Chondromyxoid fibroma of the pterygopalatine space. Laryngol Otol 1976;90:971-9.

21. Rao KVC, Rao BS, Reddy CRRM. Chondromyxoid fibroma of frontal bone: report of a case. Indian J Orthop 1976;10:137-9.

22. Thurner V], Lisanti M. Ein chondromyxoid fibroma der Stirnbeinschuppe. Zb/ Pathol Pathol Anat 1981;125:473-80.

23. Miyamoto E, Kuriyama T, Iwamoto M, Tsuji N, Shizuki K. Cranial chondromyxoid fibroma. Case report. I Neurosurg 1981;55:1001-3.

24. Watanabe Y, Goto T, Sasaki T, Yamao N, Tanji H, Kodama N. A case of chondromyxoid fibroma of the frontal bone. Neurosurgery (Tokyo) 1985;13:167-72.

25. Morimura T, Nakano A, Matsumoto T, Tani E. Chondromyxoid fibroma of the frontal bone. AJNR 1992;13:1261-4.

26. Wolf DA, Chaljub G, Maggio W, Gelman BB. Intracranial chondromyxoid fibroma. Arch Pathol Lab Med 1997;121:626-30.

27. Wu CT, Inwards CY, O'Laughlin S, Rock MG, Beabout JW, Unni KK. Chondromyxoid fibroma of bone: a clinicopathologic review of 278 cases. Hum Pathol 1998;29:438-46.

28. Baujat B, Attal P, Racy E, Quillard J, Parker F, Evennou A et al. Chondromyxoid fibroma of the nasal bone with extension into the frontal and ethmoidal sinuses: report of one case and review of the literature. Am J Otolaryngol 2001; 22:150-3.

29. Fletcher CD, Unni KK, Mertens F. World Health Organization classification of tumors. Pathology and genethics of tumors of soft tissue and bone. LYON: IARC press 2002.

30. Keel SB, Bhan AK, Liebsch NJ, Rosenberg AE. Chondromyxoid fibroma of the skull base: a tumour which may be confused with cordoma and chondrosarcoma. Am / Surg Pathol 1997;21:577-82.

31. Muller S, Whitaker B, Wheathers DR, Atlanta. Chondromyxoid fibroma of the mandible. Diagnostic image cytometry findings and review of the literature. Oral Surg Oral Med Oral Pathol 1992;73:465-8.

32. Wilson AJ, Kyriakos M, Ackerman LV. Chondromyxoid fibroma: radiographic appearance in 38 cases and in a review of the literature. Radiology 1991;179:513-8.

33. Feuvret L, Noël G, Calugaru V, Terrier P, Habrand JL. Chondromyxoid fibroma of the skull base: Differentil diagnosis and radiotherapy. Two cases and a review of the literature. Acta Oncologica 2005;44:545-53. sclerotic borders, especially in patients that are between the second and third decades in life.

Generally, if the periosteum is intact there will be no extraosseous involvement.

The benign nature of the chondromyxoid fibroma implies the importance of avoiding unnecessary radical treatment. Whenever possible, and if not too much morbidity is caused, it should be removed with sufficient margins to avoid tumor recurrence. Moreover, reconstruction with bone grafts, if necessary, should be carried out immediately after the resection.

The subcranial approach is a valid alternative for the treatment of lesions located in the frontal sinus.

A careful correlation of the clinical, radiological and histological finding should be established in order to obtain an adequate and definitive diagnosis, and treatment that will avoid any recurrence of the tumor.

Periodic radiological follow-up is essential for diagnosing promptly any possible recurrence. 